\title{
The role of disturbance in invasive plant establishment in a changing climate: insights from a drought experiment
}

\author{
Ildikó Orbán (1D) Katalin Szitár · Tibor Kalapos · György Körel-Dulay
}

Received: 31 March 2020/ Accepted: 5 February 2021 / Published online: 28 February 2021

(C) The Author(s) 2021

\begin{abstract}
Climate change and disturbance are two major factors affecting the establishment of invasive species, yet few studies to date have assessed the individual and interactive effects of these two factors in a common setting. Disturbance has often been found to facilitate the establishment of invading species, while climate change may affect them positively or negatively through altering abiotic conditions, or indirectly by modifying species interactions. In a full-factorial field experiment in a semiarid temperate grassland in Central Hungary, we studied the effects of drought (40\% rain exclusion throughout the year) and soil disturbance on the emergence, survival and aboveground biomass of four invasive plant species
\end{abstract}

Supplementary Information The online version contains supplementary material available at https://doi.org/10.1007/ s10530-021-02478-8.

I. Orbán $(\varangle)$ · T. Kalapos

Department of Plant Systematics, Ecology and

Theoretical Biology, Institute of Biology, Eötvös Loránd

University, Pázmány P. stny 1/C, Budapest 1117,

Hungary

e-mail: ildiko.orban.bio@gmail.com

I. Orbán · K. Szitár · G. Körel-Dulay

MTA Centre for Ecological Research, Institute of Ecology and Botany, Alkotmány u. 2-4, Vácrátót 2163, Hungary

G. Körel-Dulay

MTA Centre for Ecological Research, GINOP Sustainable Ecosystems Group, Klebelsberg Kunó u. 3, Tihany 8237, Hungary that represent different life forms and that are of concern in the region and at a broader scale. We added seeds of Ambrosia artemisiifolia (annual forb), Cenchrus incertus (annual grass), Asclepias syriaca (perennial forb) and Ailanthus altissima (deciduous tree) in drought and non-drought plots with and without soil disturbance. Ailanthus germinated poorly irrespective of treatments. Disturbance facilitated while drought suppressed seedling emergence in the other three species. Ambrosia was more sensitive to disturbance, while Cenchrus was more responsive to drought. Asclepias achieved substantial emergence in disturbed non-drought plots only, as drought strongly suppressed its emergence even in the presence of disturbance. Seedling survival and late-season aboveground biomass of Ambrosia and Cenchrus were positively affected by disturbance but were unaffected by drought, while no Asclepias seedling survived until late summer. Our results highlight that both drought and disturbance may considerably impact the establishment of invasive plants, with potential interactive effects, but responses may greatly differ among species and life stages. Overall, our findings in this study suggest that although drought may negatively affect seedling establishment, a drier climate may not suppress or eliminate invasive species if soil disturbance is present. They also highlight the importance of including disturbance in studies assessing the potential effects of climate change on plant invasions. 
Keywords Biological invasion - Climate change · Drought $\cdot$ Seedling emergence $\cdot$ Soil disturbance

\section{Introduction}

Ongoing climate change and biological invasions are transforming landscapes and ecosystems on a global scale (Vitousek et al. 1997; Sala et al. 2000). Each of these phenomena have a profound effect on biodiversity and ecosystem services, but their combined effects are hard to predict (Bradley et al. 2010a; Fahey et al. 2018).

Changing temperature and rainfall patterns have a direct effect on invasive species as a changing physiological constraint (Bradley et al. 2010a). Many of these species are well suited to environmental change, which facilitate their spread to new habitats in their non-native range (Bradley et al. 2010a). We may therefore expect that the same traits that make them successful invaders, such as broad environmental tolerances, high phenotypic plasticity, rapid adaptation or acclimatization to the environment, high reproductive output and growth rates, may also be beneficial under a changing climate (Bradley et al. 2010a; Davidson et al. 2011). Many studies emphasize the importance of early life stages and seedling traits in the success of invasive species (Colautti et al. 2006; Gioria and Pyšek 2017; Gioria et al. 2018). High germination rate, earlier and faster germination, and the ability to germinate under a broad range of environmental conditions are indeed frequent characteristics of invasive plant species, and have been linked to their spread, abundance, and impact (Colautti et al. 2006; Gioria and Pyšek 2017). Earlier and faster germination, and, in general, plasticity in response to changing environmental conditions may give an advantage to invasive species (compared to native ones; see e.g. Wainwright and Cleland 2013) by enabling them to exploit periods of low competition (Gioria et al. 2018) and facilitating their establishment. Therefore, several authors argue for the overall prospect of increased invasion risk under climate change (Walther et al. 2009; Bradley et al. 2012), which is indeed supported by numerous individual experimental, observational, and modelling studies (Kriticos et al. 2003; Blumenthal et al. 2008; Bradley et al. 2010b; Bellard et al. 2013). However, counterexamples also exist (Beaumont et al. 2009; Bradley 2009; Parker-Allie et al. 2009; Bellard et al. 2013) pointing to the fact that the outcome of these changes may depend on the taxonomic group (Bellard et al. 2013), functional group and the invaded habitat (Parker-Allie et al. 2009).

Besides directly influencing their physiology, phenology and demographic rates, changing precipitation and temperature also have an indirect effect on invasive species through decreasing the competitive vigor and resilience of resident communities (Walther et al. 2009). Several field studies demonstrate that invasive species benefit from the reduced biomass (Manea et al. 2016) or altered structure (Collinge et al. 2011; Jiménez et al. 2011) of the resident community. The climate-driven local decline of native species creates "vacant niches", which allows invasive species to take over (Thuiller et al. 2007).

Disturbance events disrupt ecosystems, community and populations structures by altering the physical environment (Pickett and White 1985). It has often been documented that soil disturbance facilitates the spread of invasive species through altering resource and substrate availability and offering windows of opportunity for establishment in the absence of competitors (Hobbs and Huenneke 1992; Burke and Grime 1996; Davis et al. 2000). This is due to the fact, that species that become invasive are often characterized by traits that are typical of ruderal species (sensu Grime 1977) such as high photosynthetic and growth rate (Kleunen et al. 2010), high resource use efficiency on short time scales (Funk and Vitousek 2007), traits related to high fecundity (Moravcová et al. 2010) and a light requirement for germination (Luo and Cardina 2012; Mihulka et al. 2003), which make them successful at exploiting these opportunities. Even though most studies confirm the positive effect of disturbance on invasive species, it is important to note that the effect varies from only slightly influencing single demographic rates (for example fecundity, see Larson et al. 2017) to significantly increasing invasive species' biomass (Beckstead and Augspurger 2004).The actual impact of a disturbance event may depend on its nature (i.e. how much it is part of the natural disturbance regime), severity, timing and the particular ecosystem.

Invasive species' response to disturbance may vary under different climatic conditions, making it hard to apply general findings when trying to predict their 
future spread. Therefore, carrying out species-specific manipulation experiments where plants are exposed to various levels of climatic variables is of great importance (Bradley et al. 2010a; Buckley and Csergö 2017). By combining climatic factors and disturbance, and studying species on the spectra of competitiveness, stress tolerance and response to disturbance in a comparable setting, we may also infer more general conclusions about the behaviour of invasive plants in response to global change.

The few studies to date that have tackled the effects of both climate change and disturbance on invasive species (e.g. Compagnoni and Adler 2014; Lembrechts et al. 2016) highlighted the importance of disturbance even in stressful environments, through limiting competition between invaders and resident species and increasing resource release. Furthermore, these studies conclude that there may be interaction between disturbance and climatic factors [e.g. the effect of disturbance was intensified by warming temperatures in the study of Lembrechts et al. (2016)], therefore it is important to study them in combination.

The goal of this study was to test whether drought (a frequent component of climate change), disturbance and their combination affect the emergence, survival and growth of invasive species in Central Hungary, a region heavily affected by both environmental changes and plant invasion. According to climate projections, the study area is likely to experience more frequent heatwaves and extended periods of drought in summer in the future (Jacob et al. 2014). Our study system, the sand grassland component of the Pannonian forest steppe is particularly sensitive to precipitation changes due to the low water-holding capacity of the local sandy soils. To test the combined effects of disturbance and drought in this system, we selected four invasive plant species: Ailanthus altissima (Mill.) Swingle, Ambrosia artemisiifolia (L.), Asclepias syriaca (L.) and Cenchrus incertus (M. A. Curtis). Our study species were chosen so that they represent different life forms, and their spread is of concern not only locally, but regionally and in some cases globally. Our specific objectives were to test (1) whether the emergence, survival and biomass production of these species are altered by drought, (2) if soil disturbance affects the emergence success, survival and biomass production of the chosen invasive species, and (3) whether there is any interaction between soil disturbance and drought. We hypothesized that drought would decrease the emergence, survival and biomass production, while disturbance would have a positive effect and their combined effect would be speciesspecific. Please note that although drought itself can potentially be considered as a form of disturbance, especially when it disrupts ecosystems (Pickett and White 1985), droughts are rarely discussed in a disturbance context in the literature, and throughout this manuscript disturbance does not include drought or other elements of climate change.

\section{Materials and methods}

Study site and ecosystem

The study site is located in the Duna-Tisza Interfluve in Hungary, in the Kiskunság National Park, near the village of Fülöpháza (coordinates: $46^{\circ} 52^{\prime} 17^{\prime \prime} \mathrm{N}$, $19^{\circ} 25^{\prime} 17^{\prime \prime} \mathrm{E}$, see Fig. 1). The area is characterized by a moderately warm temperate climate with continental and sub-Mediterranean influences. Mean annual mean temperature is $10.6{ }^{\circ} \mathrm{C}$, mean annual precipitation is $534.2 \mathrm{~mm}$ based on the local meteorological station's records for the period between 1936 and 2019. The calcareous sandy soil has a very high sand content (over 95\%) and a low humus content (below 1\%; Kovács-Láng et al. 2000), resulting in very low water holding capacity. Our experiment was set up at a site that has been protected and left unmanaged since the 1970s.

The broader landscape is heavily affected by human impact (mostly agricultural land-use), but the natural forest steppe vegetation prevails in fragments in protected areas. The study system is the grassland component of this forest-steppe, an open sand grassland dominated mostly by $\mathrm{C}_{3}$ perennial bunchgrasses (Festuca vaginata and Stipa borysthenica), which contribute the most to the total vascular plant cover that is around 30-40\% (Kovács-Láng et al. 2000). Other important species are perennial herbs (e.g. Artemisia campestris, Centaurea arenaria, Dianthus serotinus, Euphorbia segueriana, Fumana procumbens, Silene otites, Syrenia cana), winter annuals (e.g. Arenaria serpyllipholia, Holosteum umbellatum, Secale sylvestre) and summer annuals (e.g. Salsola kali, Bassia laniflora). The species pool of this vegetation type is relatively low (ca. 60 species), with 15-16 species $/ \mathrm{m}^{2}$ on average (Kovács-Láng et al. 

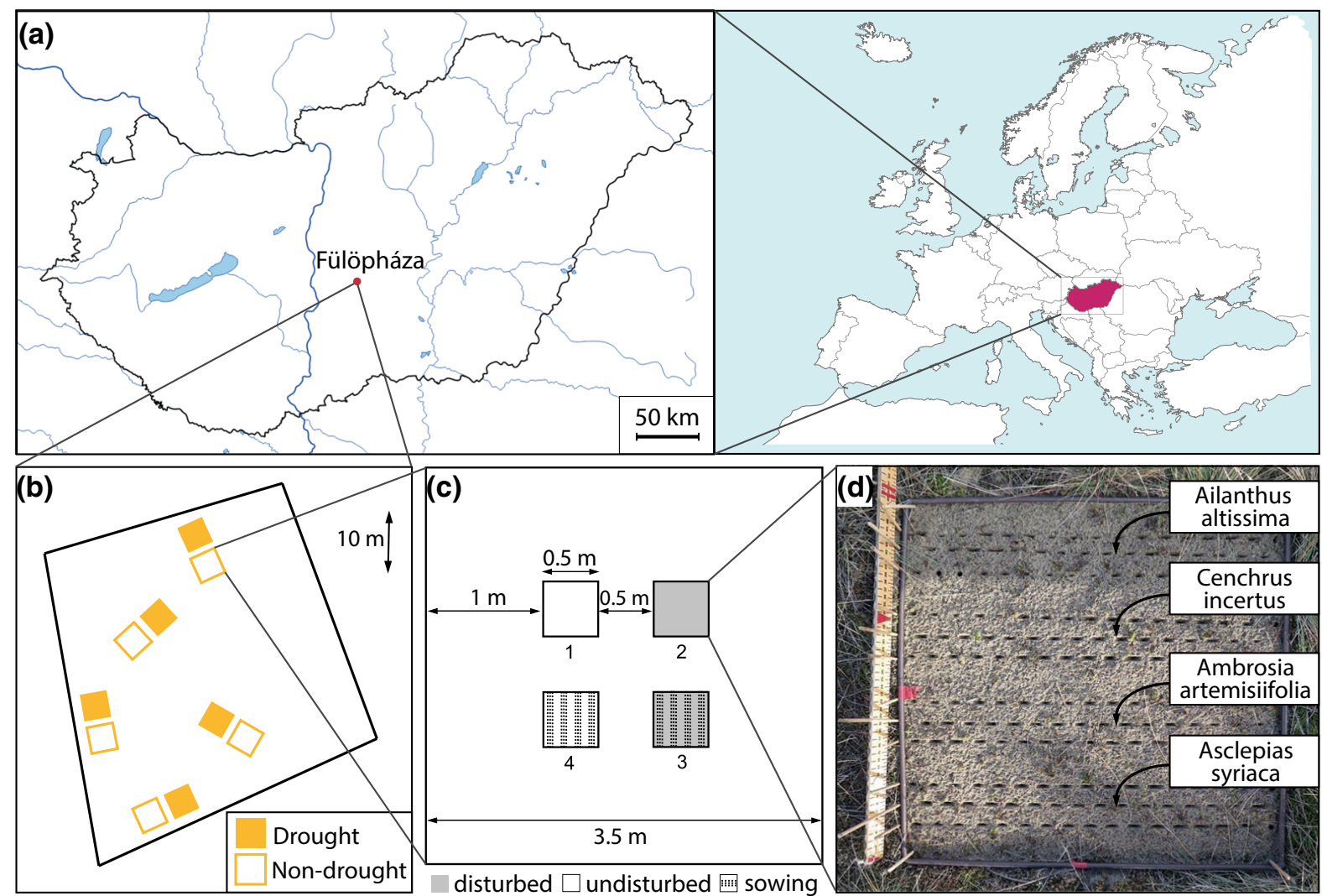

Fig. 1 a Location of the study site within Europe and Hungary; b arrangement of experimental plots (drought and non-drought); c $0.5 \mathrm{~m} * 0.5 \mathrm{~m}$ subplots designated for the sowing and

2000). The growing season starts in April and lasts until September. The major productivity peak is in May-June, and a second minor peak may occur in September.

\section{Study species}

We selected four invasive species representing different life forms that are present in the landscape, but not locally at the site, and whose spread and ecosystem effects are of major concern in the area (Botta-Dukát and Mihály 2004; Botta-Dukát and Balogh 2008). While differences among these species may highlight potential differences among life forms, we emphasize that more species of the same life from should be studied to clearly address life form specific effects.

Common ragweed (Ambrosia artemisiifolia $\mathrm{L}$.) is a widespread annual herb native to North America that has invaded the temperate regions of the world (Essl et al. 2015). The germination of ragweed seeds is disturbance treatments; $\mathbf{d}$ photo of the sowing process and the species' arrangement within the subplot

complex: after ripening, they enter a state of primary dormancy, which is broken by cold temperatures during the autumn and winter months, but seeds may also enter secondary dormancy if conditions are unfavourable and remain viable for up to 40 years (Baskin and Baskin 1977a). Generally, light stimulates germination, and germination rate decreases with soil depth, but seeds on the soil surface are exposed to more extreme conditions (cold or hot temperatures, desiccation) and experience high mortality (BottaDukát and Balogh 2008). Common sandbur (Cenchrus incertus M.A. Curtis) is an annual grass species from the subtropical and Mediterranean parts of North and Central America that had been introduced to Europe, South Africa and Australia (Szigetvári 2005), and similarly to most invasive grasses at our study site, it is characterized by $\mathrm{C} 4$ photosynthesis. The germination ecology of this species is poorly known (Szigetvári 2005), but it requires warm soil temperatures (above $20{ }^{\circ} \mathrm{C}$ according to Ujvárosi 1973). Common 
milkweed (Asclepias syriaca L.) is a tall perennial herb from the lowlands of the eastern part of North America and it is a problematic invasive alien species in the Mediterranean and temperate regions of Europe (Botta-Dukát and Balogh 2008). Seeds of these species germinate above $15{ }^{\circ} \mathrm{C}$ and prefer to be buried $0.5-1 \mathrm{~cm}$ belowground. Under optimal conditions, the germination percentage can be very high (up to 99\%), but deeply buried seeds may also retain their germination ability for years (Botta-Dukát and Balogh 2008). Tree of heaven (Ailanthus altissima (Mill.) Swingle) is a deciduous tree originating from China and Korea, and it has been introduced to subtropical and temperate regions across the world (Kowarik and Säumel 2007). Even though it is a drought-tolerant species, it requires warm and moist conditions for germination. Hereafter we will use only the genus names to refer to the study species.

\section{Experimental design}

Ten $3.5 \times 3.5 \mathrm{~m}$ plots were set up in 2016 ; they were placed on internally homogenous grassland patches in pairs (hereafter referred to as 'blocks') within a fenced experimental area (see Fig. 1b). Blocks were at least $7 \mathrm{~m}$ from each other. One plot in each block received a permanent rainout shelter built according to the design described by Smith (2017), with V-shaped polycarbonate gutters of $10 \mathrm{~cm}$ width alternating with $15 \mathrm{~cm}$ strips of non-covered areas. We excluded $40 \%$ of precipitation, all year round, thus simulating a year corresponding to the lowest 1st percentile of the longterm precipitation records. Light intensity was reduced by $13.5 \%$ under the rainout shelters, which is unlikely to severely affect ecosystem functioning, given that the study system is limited predominantly by moisture (Kovács-Láng et al. 2000). The other plot in each block was left as a control and received ambient precipitation (from here on referred to as a 'nondrought' plot).

Within each plot, four $0.5 \times 0.5 \mathrm{~m}$ subplots were designated for the experiment, surrounded by a $1 \mathrm{~m}$ outer border zone, and situated $0.5 \mathrm{~m}$ from each other (Fig. 1c). This subplot size contains individuals of the dominant species (Festuca vaginata and Stipa borysthenica) and those of the subordinate species. All subplots had similar total vascular plant cover, and none were exposed to any type of disturbance prior to the experiment. Two of the subplots were subjected to soil disturbance in the autumn of 2016: each of them was dug at approximately $20 \mathrm{~cm}$ depth, and all major vegetative plant parts were removed from the soil before putting it back and evening the ground. One of the disturbed and one of the undisturbed subplots were chosen for sowing the seeds of the study species (Fig. 1c), while the other two were left unseeded in order to check whether spontaneous dispersal and emergence happens for the studied species. This arrangement resulted in four treatment combinations for subplots with added seeds: undisturbed nondrought, disturbed non-drought, undisturbed drought, and disturbed drought.

Seeds for sowing were collected near the site during September and October 2016. In November 2016, fifty randomly chosen seeds of each invasive species were sown in each seeded subplot. The seeds of the four species were added to the same subplots, but in different sections of each subplot (Fig. 1d). Each seed was gently pushed down to approximately $3 \mathrm{~cm}$ below the surface to avoid further dispersion and thus the invasion of other plots. This depth allowed for having even the biggest seeds of Cenchrus covered with $1-1.5 \mathrm{~cm}$ layer of soil, but it was near or within the range of ideal burial depth for all other species as well [Kowarik and Säumel (2007) for Ailanthus, Jeffery and Robison (1971) for Asclepias and Guillemin and Chauvel (2011) for Ambrosia].

To avoid biased germination percentages resulting from low seed quality, we assessed the quality of collected seeds with a germination test in the laboratory. Seeds were first surface sterilized by soaking them in $5 \% \mathrm{NaOCl}$ solution for $1.5 \mathrm{~min}$ and placed on wet filter paper in Petri dishes in batches of 20. For each species, there were five replicates. The seed beds prepared this way were subjected to cold stratification at $4{ }^{\circ} \mathrm{C}$ for a time period corresponding to their germination requirements according to the literature (Pickett and Baskin 1973; Baskin and Baskin 1977b; Kowarik and Säumel 2007; Rebbeck and Jolliff 2018). After cold stratification, seed beds were placed in a growth room at a temperature of $20^{\circ} \mathrm{C}$, receiving natural light. Germination success was monitored regularly until no new seeds germinated for 10 days. The test showed that the collected seeds were viable and all species yielded high germination percentages: $71 \%( \pm 15 \% \mathrm{SE})$ of Ailanthus, $83 \%( \pm 6 \% \mathrm{SE})$ of Ambrosia, $73 \%( \pm 2 \% \mathrm{SE})$ of Asclepias and $83 \%$ ( $\pm 5 \%$ SE) of Cenchrus seeds germinated. These 
percentages were not used in any further calculations, they served only as a comparison to values reported in the literature.

\section{Data collection}

Emergence and survival of seedlings were monitored weekly from late March until July 26, 2017, when the aboveground biomass of the survived individuals was harvested by clipping them at the soil surface and pooled for each species within a subplot. Harvest was scheduled to be at the latest date without ripened seeds to prevent seed dispersal of these invasive species. The harvested biomass of each study species from each subplot was dried in an oven at $60{ }^{\circ} \mathrm{C}$ for $48 \mathrm{~h}$ and its mass was measured to $0.1 \mathrm{mg}$ accuracy.

We also recorded abiotic variables: air temperature and relative humidity were measured in each plot using a VOLTCRAFT DL-120TH type datalogger, which was taking measurements every $10 \mathrm{~min}$. Soil moisture was measured once a month between March and July using a FieldScout TDR 350 Soil Moisture Meter and a $20 \mathrm{~cm}$ rod by taking 12 measurements in each subplot. In order to avoid accidentally moving seeds further down in the soil or causing additional disturbance in the plots, we conducted these measurements in the unseeded subplots.

\section{Statistical analysis}

Since no seedlings of the sown species appeared in unseeded plots, all statistical analysis of species responses included data only from the seeded plots. Emergence percentage was calculated for each species for the twenty subplots that received seeds. Survival percentage was calculated as the proportion of germinated seeds that survived until the July 26, 2017 (date of biomass collection).

The effects of drought and soil disturbance on the emergence and survival were modelled separately for each species that yielded sufficient data by a general linear mixed model with a binomial error distribution and canonical logit-link function (package lme4, see Bates et al. 2015). This resulted in three models for emergence (for Ambrosia, Asclepias and Cenchrus) and two for survival (for Ambrosia and Cenchrus). In these models, drought, disturbance and their interaction were set as fixed factors, except for the one modelling the survival of Ambrosia, where only drought was used, since no seedlings survived in the undisturbed subplots. In all models, plot nested in block were applied as random (intercept) factors, corresponding to the split-plot design. Where overdispersion was detected (in the case of Cenchrus germination), we corrected the standard errors by applying a quasi-GLMM model. Model diagnostics was done using package dHARMA by Hartig (2020). A post-hoc comparison of means was done where the interaction of drought and disturbance turned out to be significant using the least-square means method (lsmeans function, lsmeans package, Lenth 2016).

The effects of drought and disturbance on biomass production was modelled with linear mixed effects models (package lme4, see Bates et al. 2015) for Ambrosia and Cenchrus seedlings, as only these two species' seedlings survived until the July 26, 2017. For Cenchrus, the response variable (biomass) was logtransformed [using $\log 10(x+1)$ ] in order to achieve homoscedasticity and normality of residuals. In the case of Cenchrus, drought, disturbance, and their interaction were the fixed factors, while for Ambrosia, only drought was used as a fixed factor, since no seedlings survived in undisturbed subplots. In both cases, plot nested within block were the random effects, and for Cenchrus, the variance structure was set using the varIdent function in order to allow for non-constant variance among the different levels of disturbance.

Data from soil moisture measurements were used to calculate mean volumetric water content for each subplot over all sampling dates and was analyzed further using a linear mixed model with drought, disturbance, and their interaction as fixed factors, and plot nested in block as a random factor. Air temperature and relative humidity data from the loggers (positioned at ca. $20 \mathrm{~cm}$ aboveground) were used to calculate mean daily values and to check for potential artefacts of the fixed shelters. A repeated measures linear mixed effect model was run on daily mean temperatures and relative humidity, using drought treatment and date as a fixed factor and plot nested in block as a random factor.

All data analyses were performed in $\mathrm{R}$ (Version 3.4.4, R Core Team 2020). 
Fig. 2 Emergence percentages of the four study species in different subplots $(\mathrm{n}=5)$ given as the percentage of the 50 seeds sown. Since Ailanthus emerged in very low numbers (only $2.8 \%$ of all seeds), it was omitted from further statistical analyses. For the other species, test statistics and corresponding $p$ values are the results of GLMMs. Where significant interaction was found, different letters represent significant differences between the treatment groups according to the post-hoc test $(\alpha=0.05)$

\section{Results}

\section{Abiotic factors}

The drought treatment lowered soil moisture (Supplementary table $1, \chi_{1}^{2}=19.682$, df $=1, p<0.001$ ), while disturbance $\left(\chi_{1}^{2}=0.025\right.$, df $\left.=1, p=0.874\right)$ and the interaction of drought and disturbance did not have an effect $\left(\chi_{1}^{2}=0.337, \mathrm{df}=1, p=0.561\right)$. We found only small (non-significant) differences in temperature and air humidity between drought and non-drought plots (Supplementary table 1; effect of drought on temperature: $\chi_{1}^{2}=0.029$, df $=1, p=0.865$; and on relative humidity: $\chi_{1}^{2}=0.0003, \mathrm{df}=1, p=0.986$, for measurements taken on each sampling date, see Supplementary Fig. 1).

During the study period (from November 1, 2016 to July 31,2017 ), precipitation was $384.6 \mathrm{~mm}$ and mean temperature was $9.1{ }^{\circ} \mathrm{C}$, which are close to the longterm average values $\left(8.8^{\circ} \mathrm{C}\right.$ and $405.8 \mathrm{~mm}$; 1936-2019). As the permanent shelter covered $40 \%$ of the area of the drought plots, they received an estimated $231 \mathrm{~mm}$ of precipitation. With this, we achieved a $43.1 \%$ reduction from the long-term mean, which occurred only once (in 1951) in the previous 81 years on record.

\section{Seedling emergence}

No seedlings of the study species emerged in the unseeded subplots. In the seeded subplots, three out of the four studied species emerged in considerable numbers. Overall emergence percentages were: 26.1\%, $13.5 \%$ and $37.5 \%$ for Ambrosia, Asclepias and Cenchrus, respectively. Since Ailanthus emerged in very low numbers (only $2.8 \%$ of all seeds), we omitted this species from all statistical analyses.

Drought had a negative effect on the emergence of each of the three species (Fig. 2). By contrast, soil
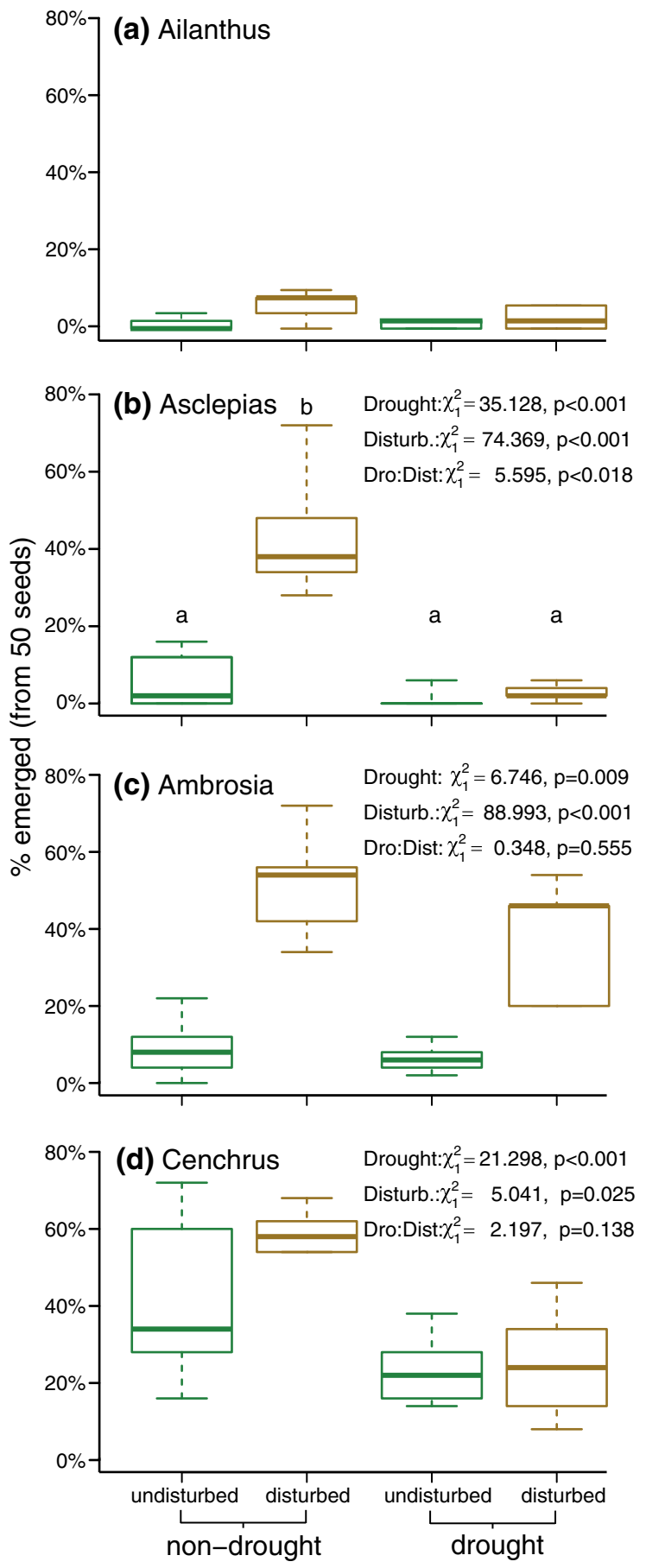

disturbance enhanced emergence in all the three species (Fig. 2). Ambrosia was more sensitive to disturbance (with mean emergence percentage of $7.8 \%$ and $44.4 \%$ in undisturbed and disturbed plots respectively), than to drought (with a mean emergence percentage of $30.4 \%$ and $21.8 \%$ in non-drought and 
drought plots, respectively). By contrast, Cenchrus was more sensitive to drought (with a mean emergence percentage of $50.6 \%$ and $24.4 \%$ in non-drought and drought plots, respectively) than to disturbance (mean emergence percentage of $32.8 \%$ and $42.2 \%$ in undisturbed and disturbed plots, respectively). The interaction of drought and disturbance was significant for Asclepias only (Fig. 2). While under non-drought conditions, mean emergence percentage increased from 6 to $44 \%$ in response to disturbance, under drought conditions it was $1.2 \%$ and $2.8 \%$ in undisturbed and disturbed plots, respectively.

Survival and late-season aboveground biomass

Asclepias seedlings died by late spring, thus survival and late-season biomass could not be evaluated. Some seedlings of Cenchrus and Ambrosia reached an adult stage, flowered and started fruit-setting, and could therefore be evaluated for survival and late-season aboveground biomass (Figs. 3 and 4).

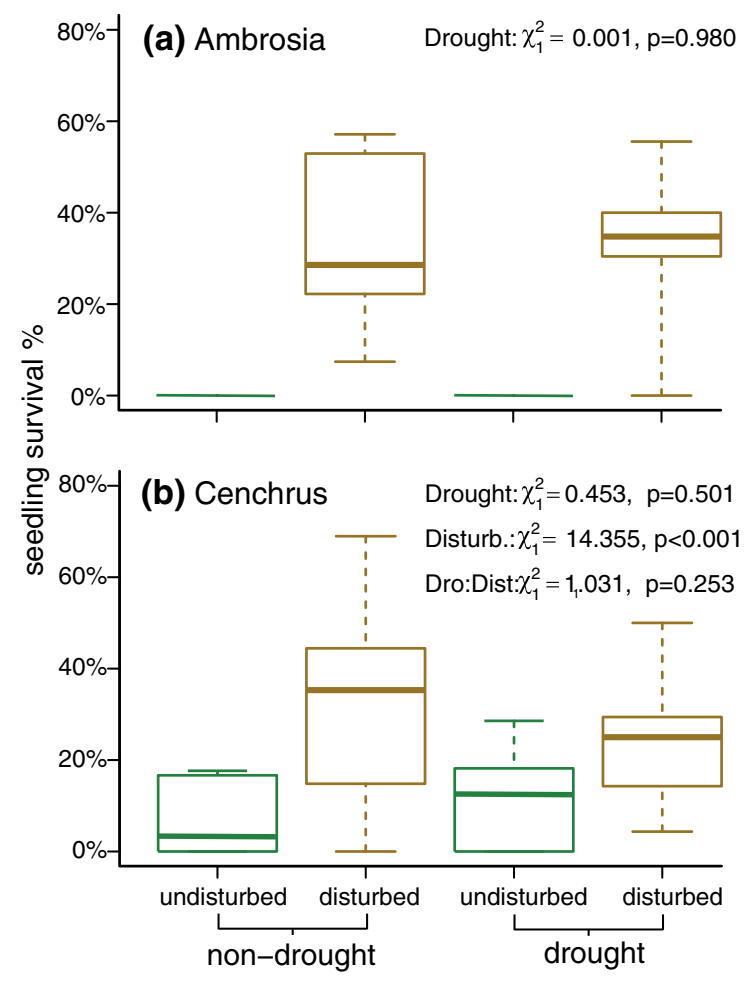

Fig. 3 Survival percentages of Ambrosia and Cenchrus seedlings in different subplots $(n=5)$. Survival is given as the percentage of germinated seeds. Test statistics and corresponding $p$ values are the results of GLMMs
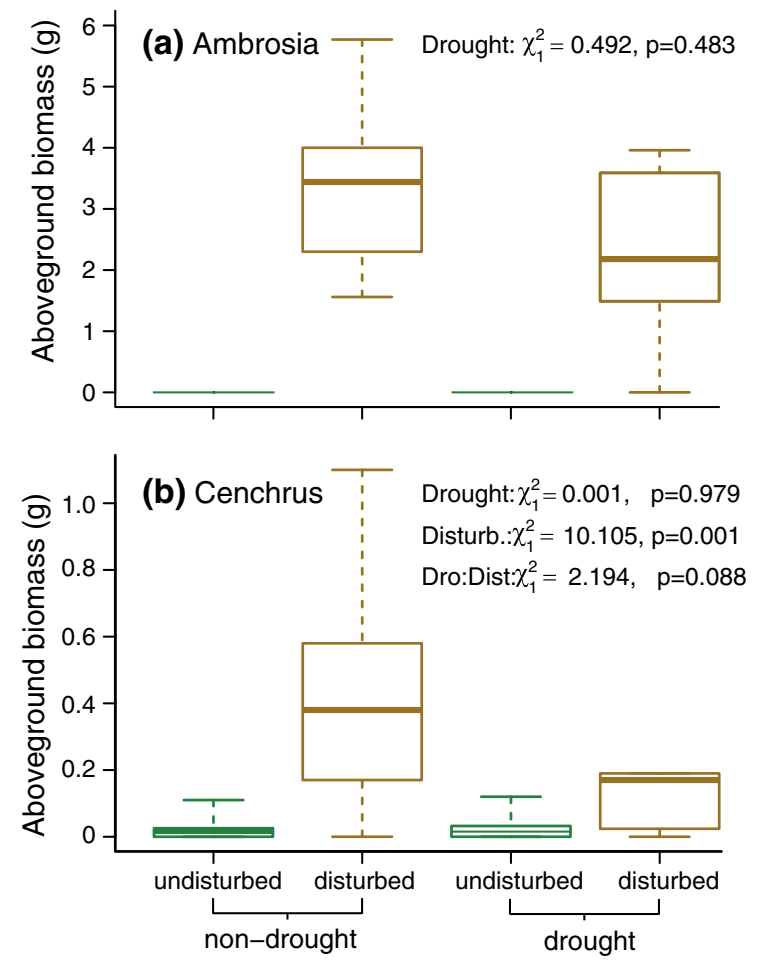

Fig. 4 Aboveground biomass of individuals of Cenchrus and Ambrosia in subplots under different treatments $(\mathrm{n}=5)$. Test statistics and corresponding $p$ values are the results of LME models

Ambrosia had surviving individuals only in disturbed plots, so the obvious effect of disturbance was not incorporated into the model assessing the effect of treatments on survival. In disturbed plots, drought affected neither survival (Fig. 3a) nor late-season above-ground biomass (Fig. 4a) for Ambrosia. For Cenchrus, disturbance had a positive effect on both survival (Fig. 3b) and late-season above-ground biomass (Fig. 4b). By contrast, drought affected neither survival (Fig. 3b), nor aboveground biomass (Fig. 4b).

\section{Discussion}

We showed that drought negatively affected emergence, while disturbance had a positive impact. However, the relative importance of drought and disturbance and of their interactive effects varied among the study species. While disturbance remained an important driver, drought did not affect the survival 
and late-season aboveground biomass. These results confirm the well-established notion of the importance of disturbance in plant invasions, while providing new insight into its role under climate change, particularly the interaction with drought, and its species and life stage specific effects.

The effect of drought on invasive species' success

Emergence percentages were relatively low (mostly below 20\%) in non-drought undisturbed plots for three out of the four species, Ailanthus, Ambrosia and Asclepias, while Cenchrus emerged in higher numbers. The fact that our viability test performed in the laboratory yielded high germination percentages (above 70\%), which are comparable to results from other studies for all the study species [see for instance Kostel-Hughes et al. (2005) for Ailanthus, Yenish et al. (1996) for Asclepias, Pickett and Baskin (1973) for Ambrosia, Zhang et al. (2016) for Cenchrus], suggests that the low numbers of emerged seedlings in our field study were not a consequence of low seed quality, but were caused by environmental conditions combined with competition from the resident vegetation. As these grasslands are primarily limited by soil moisture availability (Kovács-Láng et al. 2000), the low emergence percentages suggest that in the presence of competing resident species, water stress was probably considerably high for these species even in non-drought-plots.

The studied annual species (Ambrosia and Cenchrus, annual herb and annual C4 grass) had a higher emergence percentage than the perennials (Ailanthus and Asclepias, perennial herb and tree). Cenchrus showed the highest overall numbers, while Ambrosia emerged in slightly lower numbers. Even though little is known about the germination requirements of Cenchrus incertus, partly due to taxonomic uncertainty (Botta-Dukát and Balogh 2008) and partly to lack of studies, in line with our results, Cenchrus pauciflorus (a synonym to $C$. incertus) was found to be sensitive to water stress during its germination (Zhang et al. 2016). As for Ambrosia, laboratory studies found that drought stress during early life stages (germination and establishment) had a disproportionately negative impact on the species (Shreshta et al. 1999).

Unlike seedling emergence, survival and lateseason aboveground biomass of Ambrosia and Cenchrus were not affected by drought. This indicates that earlier life stages, especially emergence, are more sensitive to water shortage (compared with survival and growth), which may be related to the lack of a developed root system at this early stage (Walck et al. 2011; Bykova et al. 2019).

The perennial species, especially Ailanthus, emerged in lower numbers, and while Asclepias performed well in the non-drought plots, neither had any seedlings surviving to the harvest date in late summer, indicating a higher sensitivity to environmental stress. The lower emergence percentage in itself is not surprising, since these plants do not depend solely on newly established individuals each year, and, furthermore, both can spread locally by clonal growth (Kowarik and Säumel 2007; Botta-Dukát and Balogh 2008). It must be noted, however, that our study design only used one level of drought. To examine the importance of water availability further and to detect possible non-linear responses (Beier et al. 2012), it would be important for future studies to assess the effect multiple levels of drought on the invasive species throughout different years.

Since water availability is one of the most important determinants of the success of plant species in arid and semiarid grasslands, several studies have already highlighted the negative effect of drought or the importance of low soil moisture as an abiotic barrier for invasive species. For instance, Or-Leyl and Sternberg (2010) found that local communities showed a high resistance to invasion along an aridity gradient in Israel, and the survival and biomass of the invasive Conyza canadensis was negatively affected by reduced water availability. Similarly, when studying resident species' resistance and invasive species' success in a coastal prairie community, Thomsen et al. (2006) also concluded that drought represented an abiotic barrier for the invading Holcus lanatus: water addition increased the establishment and survival of this non-native species. Indeed, extraordinarily wet conditions, which may also become more frequent with climate change, may provide 'temporal hotspots' of invasion (Kreyling et al. 2008).

At our site, the intact resident vegetation was relatively resistant to the establishment of invasive species. Except for Cenchrus, their overall establishment success was low under ambient conditions in the presence of competition (without disturbance). This is generally in agreement with the notion that invasive species may possess some advantageous germination 
traits that make them successful colonizers [typical of ruderal species, e.g. large seed production, high germination rate, faster germination, broader germination niche, see for instance Pysek and Richardson (2007), Gioria and Pyšek (2017)], but, at the same time, they are weaker competitors.

The effects of disturbance on invasive species' success

Disturbance had a positive effect not only on the emergence but also in later life stages, on the survival and growth of invasive species. This is consistent with theoretical considerations that the removal of competitors supports the invasive species by creating a surplus of resources that they can utilize and gain advantage from (Davis et al. 2000; Pickett and White 1985), often by applying a resource use strategy that is more efficient on a shorter time scale than that of the resident vegetation (Funk 2013).

Species were affected somewhat differently by disturbance: Asclepias in non-drought plots yielded a much higher emergence percentage when disturbed. Previous studies demonstrate that this species is most successful on disturbed ground (Bagi 1999). Ambrosia was also very responsive to disturbance; not only did it emerge in much higher numbers in disturbed subplots, but no seedlings survived in the undisturbed subplots. The ruderal strategy and disturbance-dependent nature of this herb is evident from previous research (Fumanal et al. 2008; MacDonald and Kotanen 2010), it has been revealed that the complex germination pattern of Ambrosia is part of a competition avoidance strategy: Fenesi et al. (2014) showed that in the presence of other species of established plants, Ambrosia delayed its emergence and reduced the fraction of germinating seeds by inducing secondary dormancy. Because it is such a weak competitor, some researchers even suggested that competitor species could be included in biological control efforts against Ambrosia (Teshler et al. 2001). In the case of Cenchrus, it is noteworthy that among the studied species, it emerged in the highest numbers in the undisturbed, non-drought subplots, which may point to its better competitive ability as a seedling. However, it still benefitted from disturbance during all three studied life stages. These results are consistent with previous observations in our study area made by Szigetvári (2005), who notes that even though both annual species are tied to disturbed surfaces: while Ambrosia appears almost exclusively along the roads that are highly disturbed, Cenchrus also has several smaller stands not related to roads, but affected by mild trampling.

Even though a few previous studies found that disturbance may have a negative effect on invasive species' success (mostly when the dominant interactions between them and the resident species were facilitative rather than competitive, see Parker 2002 and Paiaro et al. 2007), in the overwhelming majority of cases its effect is beneficial, similarly to our results. This positive impact is documented in several case studies, for example on seedling establishment and survival (Fernandes et al. 2017), population growth rate (Compagnoni and Adler 2014), and biomass (Prevéy and Seastedt 2015). In a comprehensive study with several invasive species sown along elevational gradients in mountains across two continents, disturbance was found to be the primary determinant of survival, biomass production and flowering success of invasive species (Lembrechts et al. 2016). Together, these findings along with our results emphasize that studies on plant species invasiveness should include disturbance, and assessing invasibility of plant species without disturbance (e.g. Vilà et al. 2008) may potentially underestimate invasion risk.

Combined effects of drought and disturbance and their relative importance for different species

Including both drought and disturbance in our field experiment made it possible to test for potential interactive effects. Indeed, in the case of Asclepias, emergence was high only in disturbed subplots without a drought treatment, thus the positive effect of disturbance could only be manifested under nondrought conditions. One possible explanation for this is that by excluding ca. $40 \%$ of rainfall, soil moisture dropped below a species-specific stress limit that even the absence of competitors could not compensate for-and hence emergence decreased dramatically. Although all Asclepias seedlings died in this particular year, the strong negative effect of drought on seedling emergence indicates that Asclepias may be one of those alien species that will be hardly hit by drier years in the future (Or-Leyl and Sternberg 2010; Liu et al. 2017; Kelso et al. 2020). 
Interactive effects between climate and disturbance were also found by Compagnoni and Adler (2014) in their study of Bromus tectorum in Northern Utah along an elevational gradient. Neighbour removal increased the effect of warming at mid-elevations, but decreased the effect of warming at low elevations. The interaction of disturbance and elevation (which served as a proxy for air temperature) was also important in a cross-continental study of Lembrechts et al. (2016), where soils warmed up more easily in plots in which resident vegetation had been previously removed. Collectively, these findings point out that the interaction of two or more factors may result in quite different responses from invasive species, which would be hard to predict from studies investigating a single driver on its own.

Combining drought and disturbance in a single study also allowed us to compare the relative importance of the two factors. According to our results Ambrosia emergence was more sensitive to disturbance than to drought. This observation complies with studies tackling the species-specific threshold for survival of plant species in response to climatic stressors (Laube et al. 2015). Previous studies have also highlighted the predominant role of disturbance in the spread Ambrosia locally (Kröel-Dulay et al. 2018) and at its moisture-limited southern distributional limit (Storkey et al. 2014). Taking into account the role of disturbance in facilitating this particular species' spread in the future is highly important because of the projected increase in health risk due to its allergenic pollen (Storkey et al. 2014). On the other hand, the annual C4 grass species, Cenchrus, was more sensitive to drought than disturbance during emergence, but later on this changed and survival and growth was only affected by disturbance. This higher sensitivity to climatic stressors in early life stages compared to adult plants was also observed for other species (Laube et al. 2015), while in some cases, the importance of the effect of disturbance on invasive species increased towards later stages of their development (Lembrechts et al. 2016). Taken together, this highlights the importance of observing invasive species' response to different stressors and treatments throughout different life stages.

It has been previously shown that disturbance can strongly impact vegetation responses to changes in climate. Disturbed sites can be more responsive to changes in climate than undisturbed ones (Kröel-
Dulay et al. 2015), and the same site can change from unresponsive to responsive when hit by a disturbance event (Collins et al. 2017). Our study focusing on plant invasions in a changing climate provided further evidence on the role of disturbance in shaping plant responses to global change. Indeed, this experiment would have yielded much less insight into invasive species' response to drought if disturbance had not been part of the design.

\section{Conclusions}

Our results provide support for the overarching importance of disturbance in the establishment of invasive plants even in the occurrence of droughts that negatively affect seedling emergence. Interestingly, drought did not affect survival and late-season biomass of the surviving individuals, while disturbance maintained its positive effect on both, possibly through an increased resource availability due to the absence of competitors. These results suggest that although more frequent or severe future droughts may negatively affect the establishment of invasive species, a drier climate is unlikely to suppress or eliminate some of these invasive species in the event of soil disturbance. Overall, we showed that the effects of climate change on the establishment and maintenance of invasive populations should not be examined without accounting for the combined effects of disturbance.

Acknowledgements This work was supported by the National Research, Development and Innovation Fund (NRDI Fund) of Hungary (K 112576, K129068, and GINOP-2.3.2-15-201600019). We thank László Kanyó, Miklós Kertész, Gábor Ónodi and Zsuzsanna Anna Pató for field assistance. We are grateful to the Kiskunság National Park for supporting our fieldwork. We also thank the two anonymous reviewers for their detailed and constructive feedback.

Author contributions GKD and IO conceived the research and designed the experiment, IO and GKD conducted the fieldwork, IO conducted laboratory experiments, $\mathrm{KSz}$ and IO analyzed the data, IO, GKD, KSz and TK wrote the manuscript.

Funding Open access funding provided by ELKH Centre for Ecological Research. This work was supported by the National Research, Development and Innovation Fund (NRDI Fund) of Hungary (K 112,576, K129068, and GINOP-2.3.2-15-201600019). 
Open Access This article is licensed under a Creative Commons Attribution 4.0 International License, which permits use, sharing, adaptation, distribution and reproduction in any medium or format, as long as you give appropriate credit to the original author(s) and the source, provide a link to the Creative Commons licence, and indicate if changes were made. The images or other third party material in this article are included in the article's Creative Commons licence, unless indicated otherwise in a credit line to the material. If material is not included in the article's Creative Commons licence and your intended use is not permitted by statutory regulation or exceeds the permitted use, you will need to obtain permission directly from the copyright holder. To view a copy of this licence, visit http://creativecommons.org/licenses/by/4.0/.

\section{References}

Bagi I (1999) A selyemkóró (Asclepias syriaca L.)—Egy invazív faj biológiája, a védekezés lehetôségei [Common milkweed (Asclepias syriaca $\mathrm{L}$.) —biology and control of an invasive species]. Kitaibelia 4:289-295

Baskin JM, Baskin CC (1977a) Dormancy and germination in seeds of common ragweed with reference to Beal's buried seed experiment. Am J Bot 64:1174-1176

Baskin JM, Baskin CC (1977b) Germination of common milkweed (Aslcepias syriaca L.) Seeds. Torrey Bot Soc 104:167-170

Bates D, Maechler M, Bolker B, Walker S (2015) Fitting linear mixed-effects models using lme4. J Stat Softw 67:1-48. https://doi.org/10.18637/jss.v067.i01

Beaumont LJ, Gallagher RV, Downey PO et al (2009) Modelling the impact of Hieracium spp. on protected areas in Australia under future climates. Ecography 32:757-764. https://doi.org/10.1111/j.1600-0587.2009.05705.x

Beckstead J, Augspurger CK (2004) An experimental test of resistance to cheatgrass invasion: limiting resources at different life stages. Biol Invasions 6:417-432. https://doi. org/10.1023/B:BINV.0000041557.92285.43

Beier C, Beierkuhnlein C, Wohlgemuth T et al (2012) Precipitation manipulation experiments - challenges and recommendations for the future. Ecol Lett 15:899-911. https:// doi.org/10.1111/j.1461-0248.2012.01793.x

Bellard C, Thuiller W, Leroy B et al (2013) Will climate change promote future invasions? Glob Change Biol 19:3740-3748. https://doi.org/10.1111/gcb.12344

Blumenthal D, Chimner RA, Welker JM, Morgan JA (2008) Increased snow facilitates prairie invasion in mixedgrass prairie. New Phytol 179:440-448. https://doi.org/10.1111/ J.1469-8137.2008.02475.X

Botta-Dukát Z, Balogh L (2008) The most important invasive plants in Hungary. Institute of Ecology and Botany, Hungarian Academy of Sciences, Vácrátót

Botta-Dukát Z, Mihály B (2004) Biológiai Inváziók Magyarországon-Özönnövények [Biological invasions in Hungary-invasive plants]. TermészetBúVÁR Alapítvány Kiadó, Budapest
Bradley BA (2009) Regional analysis of the impacts of climate change on cheatgrass invasion shows potential risk and opportunity. Glob Change Biol 15:196-208. https://doi. org/10.1111/j.1365-2486.2008.01709.x

Bradley BA, Blumenthal DM, Wilcove DS, Ziska LH (2010a) Predicting plant invasions in an era of global change. Trends Ecol Evol 25:310-318. https://doi.org/10.1016/j. tree.2009.12.003

Bradley BA, Wilcove DS, Oppenheimer M (2010b) Climate change increases risk of plant invasion in the Eastern United States. Biol Invasions 12:1855-1872. https://doi. org/10.1007/s10530-009-9597-y

Bradley BA, Blumenthal DM, Early R et al (2012) Global change, global trade, and the next wave of plant invasions. Ecol Soc Am 10:249-257

Buckley YM, Csergő AM (2017) Predicting invasion winners and losers under climate change. Proc Natl Acad Sci 114:4040-4041. https://doi.org/10.1073/pnas.1703510114

Burke MJW, Grime JP (1996) An experimental study of plant community invasibility. Ecology 77:776-790. https://doi. org/10.2307/2265501

Bykova O, Chuine I, Morin X (2019) Highlighting the importance of water availability in reproductive processes to understand climate change impacts on plant biodiversity. Perspect Plant Ecol Evol Syst 37:20-25. https://doi.org/10. 1016/j.ppees.2019.01.003

Colautti RI, Grigorovich IA, MacIsaac HJ (2006) Propagule pressure: a null model for biological invasions. Biol Invasions 8:1023-1037. https://doi.org/10.1007/s10530005-3735-y

Collinge SK, Ray C, Gerhardt F (2011) Long-term dynamics of biotic and abiotic resistance to exotic species invasion in restored vernal pool plant communities. Ecol Appl 21:2105-2118. https://doi.org/10.1890/10-1094.1

Collins SL, Ladwig LM, Petrie MD et al (2017) Press-pulse interactions: effects of warming, $\mathrm{N}$ deposition, altered winter precipitation, and fire on desert grassland community structure and dynamics. Glob Chang Biol 23:1095-1108. https://doi.org/10.1111/gcb.13493

Compagnoni A, Adler PB (2014) Warming, competition, and Bromus tectorum population growth across an elevation gradient. Ecosphere 5:1-34. https://doi.org/10.1890/ES1400047.1

Davidson AM, Jennions M, Nicotra AB (2011) Do invasive species show higher phenotypic plasticity than native species and, if so, is it adaptive? A meta-analysis. Ecol Lett 14:419-431. https://doi.org/10.1111/j.1461-0248.2011. 01596.x

Davis MA, Grime JP, Thompson KEN (2000) Fluctuating resources in plant communities: a general theory of invasibility. J Ecol 88:528-534

Essl F, Biró K, Brandes D et al (2015) Biological glora of the British Isles: Ambrosia artemisiifolia. J Ecol 103:1069-1098. https://doi.org/10.1111/1365-2745.12424

Fahey C, Angelini C, Flory SL (2018) Grass invasion and drought interact to alter the diversity and structure of native plant communities. Ecology 99:2692-2702. https://doi. org/10.1002/ecy. 2536

Fenesi A, Albert ÁJ, Ruprecht E (2014) Fine-tuned ability to predict future competitive environment in Ambrosia 
artemisiifolia seeds. Weed Res 54:58-69. https://doi.org/ 10.1111/wre. 12048

Fernandes P, Máguas C, Correia O (2017) Combined effects of climate, habitat, and disturbance on seedling establishment of Pinus pinaster and Eucalyptus globulus. Plant Ecol 218:501-515. https://doi.org/10.1007/s11258-017-0706-1

Fumanal B, Gaudot I, Bretagnolle F (2008) Seed-bank dynamics in the invasive plant, Ambrosia artemisiifolia $\mathrm{L}$. Seed Sci Res 18:101-114. https://doi.org/10.1017/ S0960258508974316

Funk JL (2013) The physiology of invasive plants in low-resource environments. Conserv Physiol 1:1-17. https://doi. org/10.1093/conphys/cot026

Funk JL, Vitousek PM (2007) Resource-use efficiency and plant invasion in low-resource systems. Nature 446:1079-1081. https://doi.org/10.1038/nature05719

Gioria M, Pyšek P (2017) Early bird catches the worm: germination as a critical step in plant invasion. Biol Invasions 19:1055-1080. https://doi.org/10.1007/s10530-016-13491

Gioria M, Pyšek P, Osborne BA (2018) Timing is everything: Does early and late germination favor invasions by herbaceous alien plants? J Plant Ecol 11:4-16. https://doi. org/10.1093/jpe/rtw105

Grime JP (1977) Evidence for the existence of three primary strategies in plants and its relevance to ecological and evolutionary theory. Am Nat 111:1169-1194. https://doi. org/10.1086/283244

Guillemin JP, Chauvel B (2011) Effects of the seed weight and burial depth on the seed behavior of common ragweed (Ambrosia artemisiifolia). Weed Biol Manag 11:217-223. https://doi.org/10.1111/j.1445-6664.2011.00423.x

Hartig F (2020) DHARMa: Residual diagnostics for hierarchical (multi-level/mixed) regression models. $\mathrm{R}$ package version 0.3.3.0. https://CRAN.R-project.org/package=DHARMa

Hobbs RJ, Huenneke LF (1992) Disturbance, diversity, and invasion: implications for conservation. Conserv Biol 6:324-337. https://doi.org/10.1046/j.1523-1739.1992. 06030324.x

Jacob D, Petersen J, Eggert B et al (2014) EURO-CORDEX: new high-resolution climate change projections for European impact research. Reg Environ Chang 14:563-578. https://doi.org/10.1007/s10113-013-0499-2

Jeffery LS, Robison LR (1971) Growth characteristics of common milkweed. Weed Sci 19:193-196

Jiménez MA, Jaksic FM, Armesto JJ et al (2011) Extreme climatic events change the dynamics and invasibility of semiarid annual plant communities. Ecol Lett 14:1227-1235. https://doi.org/10.1111/j.1461-0248.2011.01693.x

Kelso MA, Wigginton RD, Grosholz ED (2020) Nutrients mitigate the impacts of extreme drought on plant invasions. Ecology. https://doi.org/10.1002/ecy.2980

Kleunen M, Van Weber E, Fischer M (2010) A meta-analysis of trait differences between invasive and non-invasive plant species. Ecol Lett 2:235-245. https://doi.org/10.1111/j. 1461-0248.2009.01418.x

Kostel-Hughes F, Young TP, Wehr JD (2005) Effects of leaf litter depth on the emergence and seedling growth of deciduous forest tree species in relation to seed size. J Torrey Bot Soc 132:50-61. https://doi.org/10.3159/10955674(2005)132[50:EOLLDO]2.0.CO;2
Kovács-Láng E, Kröel-Dulay G, Kertész M et al (2000) Changes in the composition of sand grasslands along a climatic gradient in Hungary and implications for climate change. Phytocoenologia 30:385-407. https://doi.org/10.1127/ phyto/30/2000/385

Kowarik I, Säumel I (2007) Biological flora of Central Europe: Ailanthus altissima (Mill.) Swingle. Perspect Plant Ecol Evol Syst 8:207-237. https://doi.org/10.1016/j.ppees. 2007.03.002

Kreyling J, Beierkuhnlein C, Ellis L, Jentsch A (2008) Invasibility of grassland and heath communities exposed to extreme weather events - additive effects of diversity resistance and fluctuating physical environment. Oikos 117:1542-1554. https://doi.org/10.1111/j.2008.00301299.16653.x

Kriticos DJ, Sutherst RW, Brown JR et al (2003) Climate change and the potential distribution of an invasive alien plant: Acacia nilotica ssp. indica in Australia. J Appl Ecol 40:111-124. https://doi.org/10.1046/j.1365-2664.2003. 00777.x

Kröel-Dulay G, Ransijn J, Schmidt IK et al (2015) Increased sensitivity to climate change in disturbed ecosystems. Nat Commun 6:6682. https://doi.org/10.1038/ncomms7682

Kröel-Dulay G, Csecserits K, Szitár K et al (2018) The potential of common ragweed for further spread: invasibility of different habitats and the role of disturbances and propagule pressure. Biol Invasions 21:137-149. https://doi. org/10.1007/s10530-018-1811-3

Larson CD, Lehnhoff EA, Rew LJ (2017) A warmer and drier climate in the northern sagebrush biome does not promote cheatgrass invasion or change its response to fire. Oecologia 185:763-774. https://doi.org/10.1007/s00442017-3976-3

Laube J, Ziegler K, Sparks TH et al (2015) Tolerance of alien plant species to extreme events is comparable to that of their native relatives. Preslia 87:31-53

Lembrechts JJ, Pauchard A, Lenoir J et al (2016) Disturbance is the key to plant invasions in cold environments. Proc Natl Acad Sci 113:14061-14066. https://doi.org/10.1073/pnas. 1608980113

Lenth RV (2016) Least-squares means: the R package 1smeans. J Stat Softw 69:1-33. https://doi.org/10.18637/jss.v069.i01

Liu Y, Oduor AMO, Zhang Z et al (2017) Do invasive alien plants benefit more from global environmental change than native plants? Glob Change Biol 23:3363-3370. https:// doi.org/10.1111/gcb.13579

Luo J, Cardina J (2012) Germination patterns and implications for invasiveness in three Taraxacum (Asteraceae) species. Weed Res 52:112-121. doi:https://doi.org/10.1111/j.13653180.2011.00898.x

MacDonald AAM, Kotanen PM (2010) The effects of disturbance and enemy exclusion on performance of an invasive species, common ragweed, in its native range. Oecologia 162:977-986. https://doi.org/10.1007/s00442-009-1557-9

Manea A, Sloane DR, Leishman MR (2016) Reductions in native grass biomass associated with drought facilitates the invasion of an exotic grass into a model grassland system. Oecologia 181:175-183. https://doi.org/10.1007/s00442016-3553-1

Mihulka S, Pyšek P, Martínková J (2003) Invasiveness of Oenothera congeners in Europe related to seed 
characteristics. In: Child L, Brock JH, Brundu G, Prach K, Pyšek P, Wade M, Williamson M (eds) Plant invasions: ecological threats and management solutions. Backhuys Publishers, Leiden, pp 213-225

Moravcová L, Pyšek P, Jarošík V et al (2010) Reproductive characteristics of neophytes in the Czech Republic: traits of invasive and non-invasive species. Preslia 82:365-390

Or-Leyl H-E, Sternberg M (2010) Invasive species and climate change: Conyza canadensis (L.) Cronquist as a tool for assessing the invasibility of natural plant communities along an aridity gradient. Biol Invasions 12:1953-1960. https://doi.org/10.1007/s10530-009-9640-z

Paiaro V, Mangeaud A, Pucheta E (2007) Alien seedling recruitment as a response to altitude and soil disturbance in the mountain grasslands of central Argentina. Plant Ecol 193:279-291. https://doi.org/10.1007/s11258-007-9265-1

Parker IM (2002) Safe site and seed limitation in Cytisus scoparius (Scotch broom): invasibility, disturbance, and the role of cryptogams in a glacial outwash prairie. Biol Invasions 3:323-332. https://doi.org/10.1023/A: 1015855515361

Parker-Allie F, Musil CF, Thuiller W (2009) Effects of climate warming on the distributions of invasive Eurasian annual grasses: a South African perspective. Clim Change 94:87-103. https://doi.org/10.1007/s10584-009-9549-7

Pickett STA, Baskin JM (1973) The role of temperature and light in the germination behavior of Ambrosia artemisiifolia. Bull Torrey Bot Club 100:165. https://doi.org/10. 2307/2484628

Pickett AT, White PS (1985) The ecology of natural disturbances and patch dynamics. Academic Press, New York

Prevéy JS, Seastedt TR (2015) Effects of precipitation change and neighboring plants on population dynamics of Bromus tectorum. Oecologia 179:765-775. https://doi.org/10. 1007/s00442-015-3398-z

Pysek P, Richardson DM (2007) Traits associated with invasiveness in alien plants: Where do we stand? In: Nentwig W (ed) Biological studies. Springer-Verlag, Berlin Heidelberg, pp 97-125

R Core Team (2020) R: A language and environment for statistical computing. R Foundation for Statistical Computing, Vienna, Austria. https://www.R-project.org/

Rebbeck J, Jolliff J (2018) How long do seeds of the invasive tree, Ailanthus altissima remain viable? For Ecol Manag 429:175-179. https://doi.org/10.1016/j.foreco.2018.07. 001

Sala OE, Chapin FS, Armesto JJ et al (2000) Global biodiversity scenarios for the year 2100. Science 287:1770-1774. https://doi.org/10.1126/science.287.5459.1770

Shreshta A, Roman ES, Thomas AG, Swanton CJ (1999) Modeling germination and seedling elongation of $\mathrm{Am}$ brosia artemisiifolia. Weed Sci 47:557-562. https://doi. org/10.1002/hep.22563

Smith M (2017) The international drought experiment: a distributed approach to assess terrestrial ecosystem responses to extreme drought-short-stature systems. https:// drought-net.colostate.edu/sites/default/files/the

international_drought_experiment_draft_protocol_v4.pdf. Accessed 21 November 2020
Storkey J, Stratonovitch P, Chapman DS et al (2014) A processbased approach to predicting the effect of climate change on the distribution of an invasive allergenic plant in Europe. PLoS One 9:1-7. https://doi.org/10.1371/journal. pone. 0088156

Szigetvári C (2005) Distribution and phytosociological relations of two introduced plant species in an open sand grassland area in the Great Hungarian Plain. Acta Bot Hung 44:163-183. https://doi.org/10.1556/ABot.44.2002.1-2.12

Teshler MP, Ditommaso A, GJ A, Watson AK, (2001) Ambrosia artemisiifolia L. common ragweed (Asteraceae). In: Mason PG, Huber JT (eds) Biological control programs in Canada 1981-2000. CABI, Wallingford, pp 290-294

Thomsen MA, D'Antonio CM, Suttle KB, Sousa WP (2006) Ecological resistance, seed density and their interactions determine patterns of invasion in a California coastal grassland. Ecol Lett 9:160-170. https://doi.org/10.1111/j. 1461-0248.2005.00857.x

Thuiller W, Richardson DM, Midgley GF (2007) Will climate change promote alien plant invasions? In: Nentwig W (ed) Ecological studies, vol 193: biological invasions. Springer, Heidelberg, pp 197-211

Ujvárosi M (1973) Gyomnövények. [Weeds]. Mezőgazdasági Kiadó, Budapest

Vilà M, Siamantziouras ASD, Brundu G et al (2008) Widespread resistance of Mediterranean island ecosystems to the establishment of three alien species. Divers Distrib 14:839-851. https://doi.org/10.1111/j.1472-4642.2008. 00503.x

Vitousek PM, Mooney HA, Lubchenco J, Melillo JM (1997) Human domination of Earth's ecosystems. Science 277:494-499. https://doi.org/10.1126/science.277.5325. 494

Wainwright CE, Cleland EE (2013) Exotic species display greater germination plasticity and higher germination rates than native species across multiple cues. Biol Invasions 15:2253-2264. https://doi.org/10.1007/s10530-013-04494

Walck JL, Hidayati SN, Dixon KW et al (2011) Climate change and plant regeneration from seed. Glob Chang Biol 17:2145-2161

Walther GR, Roques A, Hulme PE et al (2009) Alien species in a warmer world: risks and opportunities. Trends Ecol Evol 24:686-693. https://doi.org/10.1016/j.tree.2009.06.008

Yenish JP, Fry TA, Durgan BR, Wyse DL (1996) Tillage effects on seed distribution and common milkweed (Asclepias syriaca). Weed Sci 44:815-820

Zhang Z, Tian X, Bai Y et al (2016) Field sandbur (Cenchrus pauciflorus) seeds in the same bur respond differently to temperature and water potential in relation to germination in a semi-arid environment, China. PLoS ONE 11:1-14. https://doi.org/10.1371/journal.pone.0168394

Publisher's note Springer Nature remains neutral with regard to jurisdictional claims in published maps and institutional affiliations. 